\title{
Virus-neutralizing antibody response of mice to consecutive infection with human and avian influenza $A$ viruses
}

\author{
J. JANULÍKOVÁ, A. STROPKOVSKÁ, Z. BOBIŠOVÁ, I. KOŠÍK, V. MUCHA, F. KOSTOLANSKÝ, E. VAREČKOVÁ*
}

Institute of Virology, Slovak Academy of Sciences, Dúbravská cesta 9, 84505 Bratislava, Slovak Republic

Received April 16, 2015; accepted May 19, 2015

\begin{abstract}
Summary. - In this work we simulated in a mouse model a naturally occurring situation of humans, who overcame an infection with epidemic strains of influenza A, and were subsequently exposed to avian influenza A viruses (IAV). The antibody response to avian IAV in mice previously infected with human IAV was analyzed. We used two avian IAV (A/Duck/Czechoslovakia/1956 (H4N6) and the attenuated virus rA/Viet Nam/12032004 (H5N1)) as well as two human IAV isolates (virus A/Mississippi/1/1985 (H3N2) of medium virulence and A/Puerto Rico/8/1934 (H1N1) of high virulence). Two repeated doses of IAV of H4 or of H5 virus elicited virus-specific neutralizing antibodies in mice. Exposure of animals previously infected with human IAV (of $\mathrm{H} 3$ or $\mathrm{H} 1$ subtype) to IAV of $\mathrm{H} 4$ subtype led to the production of antibodies neutralizing $\mathrm{H} 4$ virus in a level comparable with the level of antibodies against the human IAV used for primary infection. In contrast, no measurable levels of virus-neutralizing (VN) antibodies specific to $\mathrm{H} 5$ virus were detected in mice infected with $\mathrm{H} 5$ virus following a previous infection with human IAV. In both cases the secondary infection with avian IAV led to a significant increase of the titer of $\mathrm{VN}$ antibodies specific to the corresponding human virus used for primary infection. Moreover, cross-reactive HA2-specific antibodies were also induced by sequential infection. By virtue of these results we suggest that the differences in the ability of avian IAV to induce specific antibodies inhibiting virus replication after previous infection of mice with human viruses can have an impact on the interspecies transmission and spread of avian IAV in the human population.
\end{abstract}

Keywords: avian influenza A viruses; sequential influenza A infection; antibody response; virus-neutralizing antibodies; HA2-specific antibodies; original antigenic sin

\section{Introduction}

Severe human infections caused by avian influenza A viruses (IAV) of H5N1 subtype were first reported in the year 1997 (De Jong et al., 1997; Subarrao et al., 1998; Subbarao and Katz, 2000). Since then, sporadic human infections by avian IAV of H5N1 and other HA subtypes have occurred with a fatality rate of close to $60 \%$ (Chen et al., 2014; Freidl

*Corresponding author. E-mail: viruevar@savba.sk; phone: +4212-59302427.

Abbreviations: $\mathrm{HA}=$ hemagglutinin; $\mathrm{IAV}=$ influenza A virus; $\mathrm{MAb}=$ monoclonal antibody; OAS = original antigenic sin; $\mathrm{VN}=$ virus-neutralizing et al., 2014; WHO report, 2014). Thus avian IAV, mainly of $\mathrm{H} 5$ and $\mathrm{H} 7$ subtypes, as well as originally swine, later human pandemic influenza $\mathrm{A}(\mathrm{H} 1 \mathrm{~N} 1)$ pdm09 virus with its avian ancestors, still pose a pandemic threat to humans (Hatta and Kawaoka, 2002; Subarrao et al., 2006; Garten et al., 2009). The interspecies transmission of IAV is a complex process resulting from many interactions between the virus and the host. Thus, both viral and host factors determine the disease severity, the course of infection and its outcome (Cheung et al., 2002; Seo et al., 2002, 2004; Webster, 2006; Wong and Yuen, 2006; Sandrock and Kelly, 2007; Chandrasekaran et al., 2008; Blazejewska et al., 2011; Boivin et al., 2011; Gabriel et al., 2011; Schmolke et al., 2011; Horby et al., 2012; Imai and Kawaoka, 2012; Kaplan and Webby, 2013; Gabriel et 
al., 2013). There are however only limited studies on the interaction of avian IAV with the human immune system. Several studies on subclinical infections in humans based on serological analysis of individuals who had been in contact with infected poultry (Chang SY et al., 2013; Liu et al., 2013) have been reported, but it is difficult to predict the outcome of the exposure of humans to non-adapted avian viruses. The analysis of the reaction of immune system to these inter-species influenza infections could therefore get us closer to understanding the ability of non-adapted IAV to spread among humans and to cause severe disease. The fact that some influenza A (H7N9) viruses isolated from humans displayed features suggesting partial adaptation to mammals (Hui and Hayden, 2014; Wang et al., 2014) could be important from the epidemiological point of view. It could help to elucidate how the immune response of humans exposed to avian viruses can influence the IAV virus spread in the human population. The main role in this process is played by virus-neutralizing antibodies which are of narrow strain-specificity (Kostolansky et al., 2000). In the case of zoonotic infections, it is exclusively the heterosubtypic immune response that can be effective in the reduction of virus replication. Such heterosubtypic antibody response is targeted at the shared, conserved parts of influenza virus antigens, including HA (Gocnik et al., 2008; Varečková et al., 2008; Stropkovska et al., 2009; Sui et al., 2009; Bommakanti et al., 2010; Prabhu et al., 2010; Wang et al. 2010; Janulikova et al., 2012; Du et al., 2013; Stanekova et al., 2013).

In this study we focused on the interaction of the virus and the host immune system and analyzed the antibody response of mice to the avian IAV. By the sequential double infection of mice with human and avian viruses we simulated the situation in nature, when individuals previously infected with human viruses, or vaccinated with influenza vaccine, come into the contact with avian IAV. The main goal was to examine how a previous infection of mice with human viruses influences the induction of antibodies inhibiting the replication of avian viruses.

\section{Material and Methods}

Viruses. Human viruses A/Mississippi/1/1985 (H3N2) - "A/Miss" and A/Puerto Rico/8/1934 (H1N1) - "A/PR8" were adapted to mice according to Fislova et al. (2009). Avian virus, low pathogenic (LPAI) A/Duck/Czechoslovakia/1956 (H4N6) - "A/Duck" did not replicate in mice even after multiple passaging in mouse lungs, though it was fully replicating in vitro in MDCK cells as well as in fertilized chicken eggs. Therefore, a non-adapted A/Duck was used in all experiments. On exposure of mice to this virus, the presence of viral mRNA as well as the synthesis of viral proteins were proven in mouse lungs. Another model virus, the recombinant of highly pathogenic (HPAI) H5N1 A/Viet Nam/1203-2004 (H5N1)
"rA/Vietnam" virus, containing HA and NA from A/Viet Nam/12032004 of avian H5N1 virus, internal proteins (PB2, PA, NP, NS, M) from A/PR8/1934 H1N1virus and PB1 from A/Texas/1977 (H3N2) virus was attenuated by deleting the multi-basic cleavage site between HA1 and HA2 in HA molecule and was adapted to mice as described before (Fislová et al., 2009). All virus stocks used in this work (except rA/Vietnam), originated from the collection of viruses at the Institute of Virology, Slovak Academy of Sciences, Bratislava, Slovak Republic. Virus rA/Vietnam was kindly provided by Dr. Ferko and Dr. Romanova (GHB, Vienna, Austria). Viruses were propagated in 10-day-old fertilized chicken eggs for $48 \mathrm{hr}$ at $35^{\circ} \mathrm{C}$. Infectious allantoic fluid was aliquoted and stored at $-80^{\circ} \mathrm{C}$. The virus titer was evaluated by a standard micro-hemagglutination assay using guinea pig erythrocytes. Purified viruses were prepared from the infectious allantoic fluid by differential centrifugation in sucrose gradients (Russ et al., 1976).

EHA2. EHA2 was expressed in Escherichia coli BL21 transformed with pLM-1 plasmid encoding the region of aa 23-185 of HA2 gp of recombinant X-31 virus (H3N2). The latter originated from A/Aichi/2/1968 (H3N2) virus, kindly provided by Drs D.C. Wiley and J. Chen, Harvard University, Boston, USA. EHA2 was purified as previously described (Janulíková et al., 2012).

Plaque assay. Virus was titrated by a standard plaque assay method (Varečková et al., 2003).

Animal experiments. Six-week-old female BALB/c mice (Faculty of Medicine, Masaryk University, Brno, Czech Republic) were used for infection. Mice were infected intranasally under a light narcosis with the appropriate dose of influenza virus (30-50 PFU/mouse or as indicated) in a volume $40 \mu \mathrm{l} /$ mouse.

Preparation of mouse-adapted viruses. Adaptation of human influenza A viruses A/Miss (H3N2) and A/PR8 (H1N1) to mice has been described before (Fislová et al., 2009). Avian influenza virus A/Duck (H4N6) and rA/Vietnam (H5N1) were adapted to mice as follows: Two 6-week old BALB/c mice were infected intranasally under a light anesthesia with $40 \mu \mathrm{l}$ of allantoic fluid containing virus. Their lungs were harvested 2 days after the infection. Lungs were homogenized in $1 \mathrm{ml}$ of PBS, pH 7.2. Cell debris was sedimented and supernatant $(40 \mu \mathrm{l})$ was used for further infection. After 6 passages, the viruses were propagated in 10-day old chicken embryos for 48 or $36 \mathrm{hr}$. The infectious dose of lethal viruses for mice was estimated by the titration of mouse-adapted virus on mice and the median lethal dose (LD50) was determined according to Reed and Muench (1938).

Ethical statement. All animal experiments were performed in accordance with the European Union standards and the fundamental ethical principles including animal welfare requirements were respected. Experiments with avian influenza viruses were conducted under BSL-3 containment, including work with animals.

Sera collection. Blood was obtained from the facial vein of mice before and 14 days after each infection and serum was prepared by standardly used protocol.

Preparation of detector peroxidase-labeled monoclonal antibody (MAb): NP-specific MAb 107L was conjugated to horse- 
radish peroxidase according to the protocol described in work by Tkáčová and Varečková (1996).

Virus-neutralization micro-assay. Two-fold dilutions of mouse sera in phosphate buffered saline (PBS, $\mathrm{pH} 7.2$ ) were mixed with 8 $\mathrm{TCID}_{50}$ of virus in a volume ratio of $1: 1$. After incubation at $25^{\circ} \mathrm{C}$ for $60 \mathrm{~min}$, the mixture of virus with the appropriate dilutions of serum $(100 \mu \mathrm{l})$ was added to a confluent monolayer of MDCK cells cultured in a 96-well plate. Infectious virus was adsorbed onto the cells for $45 \mathrm{~min}$ at $25^{\circ} \mathrm{C}$. Cell monolayers were washed with PBS and $100 \mu \mathrm{l}$ of serum-free ULTRA-MDCK medium containing $4 \mu \mathrm{g} / \mathrm{ml}$ of TPCK-trypsin was added per well and incubated at $37^{\circ} \mathrm{C}$ in a humid atmosphere of $5 \% \mathrm{CO}_{2}$. After $18 \mathrm{hr}$ of infection, cell monolayers were washed three times with PBS and fixed with cold methanol at $+4^{\circ} \mathrm{C}$ for $15 \mathrm{~min}$. Replicated virus was detected by HRP-labeled monoclonal antibody 107L-Px specific for influenza A nucleoprotein as previously described (Varečková et al., 2002). The reaction was stopped after $1 \mathrm{hr}$ of incubation at $37^{\circ} \mathrm{C}$ and visualized with the substrate solution $(100 \mu \mathrm{l} /$ well $)$ of 3-amino-9-ethylcarbazol containing hydrogen peroxide $(0.03 \%)$. After an approximately $30 \mathrm{~min}$. incubation at $25^{\circ} \mathrm{C}$, the plates were washed and evaluated microscopically. The distinctly red-colored cells were considered positive for infection. The titer of virus-neutralization antibodies was defined as the reciprocal value of the highest serum dilution, at which differentiated red intracellular staining was still visible.

ELISA binding test. Antigen (purified virus $300 \mathrm{ng} / 100 \mu \mathrm{l} /$ well or purified EHA2 $30 \mathrm{ng} / 100 \mu \mathrm{l} /$ well) diluted in PBS, pH 7.2 was adsorbed to the 96 -well microtitration plate overnight at $4^{\circ} \mathrm{C}$. Plates were then washed 3 times with PBS, pH 7.2 and virus was treated with the McIlvain solution, $\mathrm{pH} 5$ for $30 \mathrm{~min}$. at $25^{\circ} \mathrm{C}$. Subsequently the plates were washed and saturated with $0.5 \%$ ovalbumin for 1 hour at $25^{\circ} \mathrm{C}$. Serial 2 -fold serum dilutions $(100 \mu \mathrm{l} /$ well $)$ were then added and incubated for $90 \mathrm{~min}$ at $25^{\circ} \mathrm{C}$. After 3 washes $(0.02 \%$ Tween 20 in PBS), a goat anti-mouse IgG conjugated with horseradish peroxidase (GAM-Ig-Px, Bio-Rad) diluted 3000-times in $0.5 \%$ ovalbumin was added. Following $90 \mathrm{~min}$ incubation at $25^{\circ} \mathrm{C}$ and 3 washes, the reaction was visualized by the addition of peroxidase substrate solution OPD (o-phenylendiamine) containing $0.03 \% \mathrm{H}_{2} \mathrm{O}_{2}$ and absorbancy at $492 \mathrm{~nm}$ was measured.

\section{Results}

We focused on specific antibody response induced after the infection of mice with human or/and avian influenza A viruses. The aim of this work was to analyze the level of biologically active antibodies specific to avian IAV following previous exposure to human IAV. Mouse-adapted human viruses of $\mathrm{H} 1$ and $\mathrm{H} 3$ subtypes and avian viruses of $\mathrm{H} 4$ and H5 subtypes were used for infection.

We used two human IAV strains differing in virulence and pathogenicity, A/PR8 of H1 subtype of high virulence and A/Miss of $\mathrm{H} 3$ subtype of medium virulence, and two avian IAV strains non-lethal for mice, non-replicating virus
A/Duck of H4 subtype and replicating virus A/Vietnam of $\mathrm{H} 5$ subtype. In all experiments, mice were primarily infected with a sublethal dose of human virus of $\mathrm{H} 1$ or $\mathrm{H} 3$ subtype $\left(0.1 \mathrm{LD}_{50}\right)$. Two weeks after the primary infection, two subsequent identical doses of infectious avian virus (A/Duck or A/Vietnam) were intranasally applied to mice in a 14-day interval. The levels of $\mathrm{VN}$ antibodies specific to avian IAV as well as to human viruses were analyzed.

\section{Analysis of the virus-neutralizing antibody response of} mice infected with human IAV and subsequently exposed to avian IAV A/Duck (H4N6)

We showed that no $\mathrm{VN}$ antibodies specific to A/Duck were induced after a single dose of $\mathrm{H} 4$ virus, but a significant $\mathrm{VN}$ titer was observed after the second and third infective dose of this virus (Fig. 1). A previous infection of mice with human viruses of $\mathrm{H} 1$ or $\mathrm{H} 3$ subtype did not significantly influence the level of A/Duck-specific VN antibodies, regardless of the HA subtype of the human IAV used for primary infection. The VN titers ranged between 256 and 1024 .

The VN antibodies specific to the human virus used for primary infection (H1 or H3 subtype), were already induced after a single dose of these viruses and their titers reached the values of 1200 and 1600 for $\mathrm{H} 3$ and $\mathrm{H} 1$ viruses, respectively. Surprisingly, the titer of $\mathrm{VN}$-antibodies specific to the primary human virus increased after the subsequent repeated exposure of mice to the avian virus of $\mathrm{H} 4$ subtype and ranged from 2000 to 3200 (Fig. 1).

Antigen-specificity of antibodies elicited after infection with non-replicating avian virus of $\mathrm{H} 4$ subtype in mice which had been previously exposed to well-replicating mouseadapted human IAV of $\mathrm{H} 3$ subtype was analyzed by ELISAbinding test. The first group $(n=3)$ represented mice infected with three repeated doses (6.4 PFU/mouse) of A/Duck (H4N6) virus. The second group represented mice $(n=3)$ infected with one sub-lethal dose of A/Miss (H3N2) virus and then with an identical dose of avian A/Duck (H4N6) virus. The other two groups of mice were infected according to the same scheme, but with 10-times higher doses of virus i.e. $64 \mathrm{PFU} / \mathrm{mouse}$. The levels of antibodies specific to both viruses used for infection (A/Duck and A/Miss) were evaluated by ELISA-binding test (Fig. 2). We showed that primary infection of mice with A/Miss virus also elicited antibodies which cross-reacted with $\mathrm{A} / \mathrm{Duck}$ virus and vice versa, regardless of the infectious dose of avian virus.

The cross-reactivity of antibodies induced by the double infection described above could be attributed to the immune stimulation by the highly conserved internal antigens. In these sera, however, a subpopulation of antibodies reactive with HA2 of H3 subtype was also present, and the level of these antibodies increased markedly following infection with heterologous virus of $\mathrm{H} 4$ subtype (Fig. 2). 
(a)

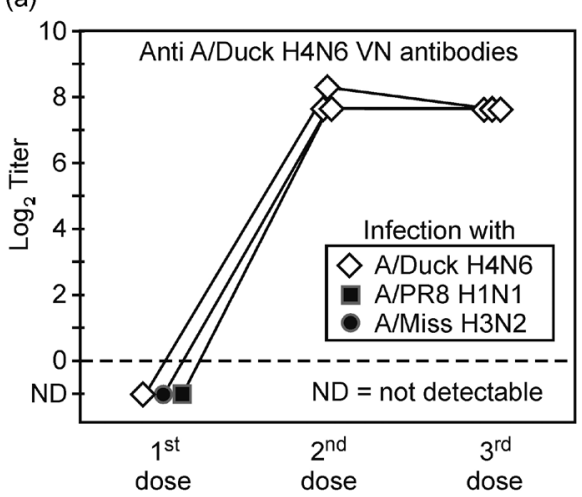

(b)

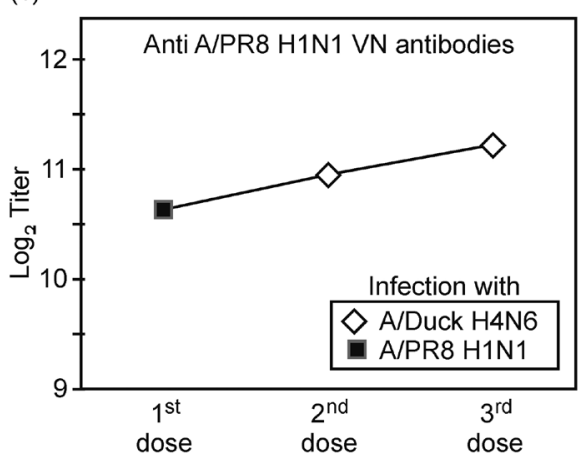

(c)

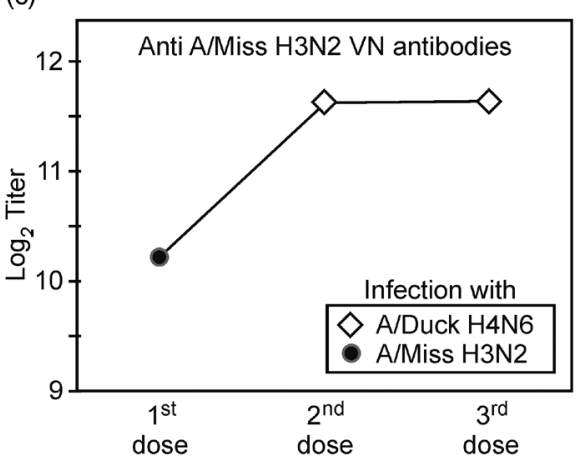

Fig. 1

Titers of virus-neutralizing antibodies specific to virus A/Duck (H4 subtype, avian) (a), A/Miss (H3 subtype, human) (b) or A/PR8 (H1 subtype, human) (c) in sera of BALB/c mice infected with repeated doses of A/Duck virus, or infected with one sublethal dose of human IAV (H1 or H3) and subsequently with two identical doses of avian (H4) virus
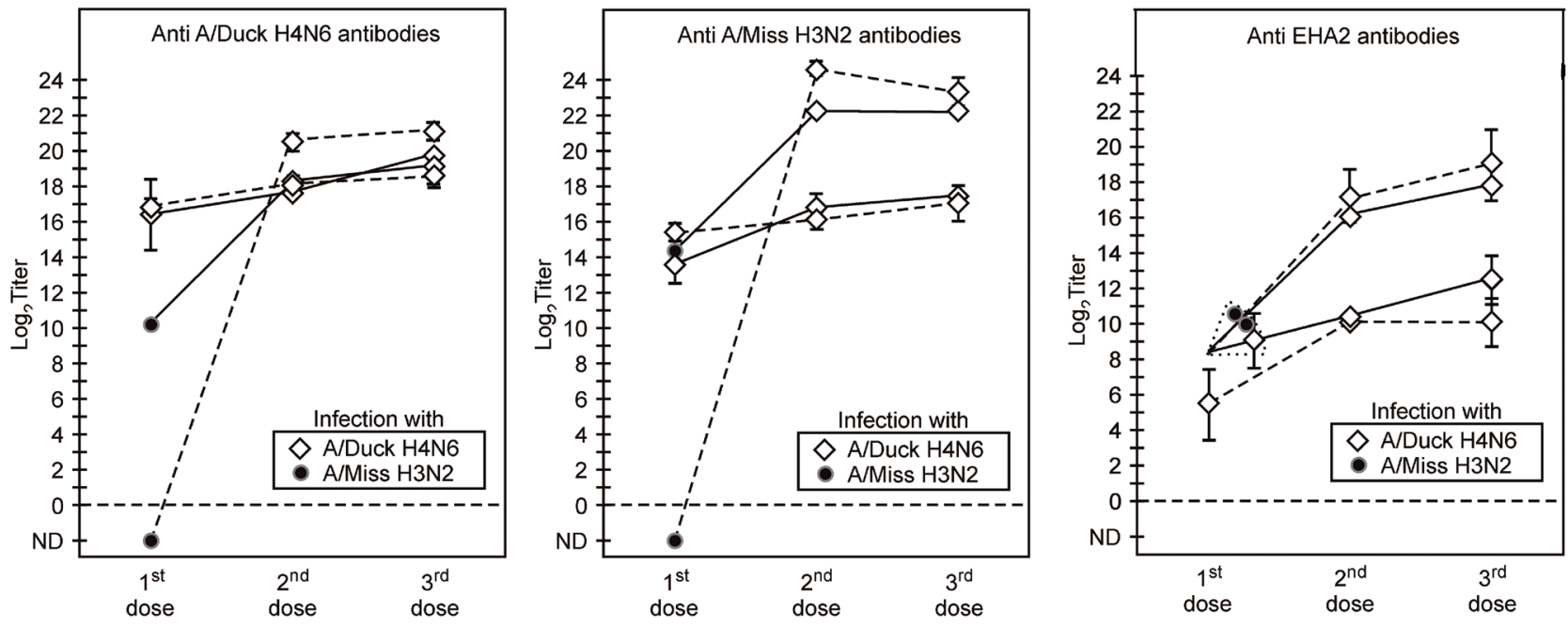

Fig. 2

Titers of virus-specific antibodies induced in sera of mice infected with A/Duck virus or with sublethal dose of A/Miss virus followed by the infection with two doses of A/Duck virus

Titers were estimated by ELISA binding test with purified influenza viruses A/Duck (H4 subtype-avian), A/Miss (H3 subtype-human) and with purified EHA2 of IAV of H3 subtype. The two diferent virus doses are plotted with continuous line (64.0 PFU) or dashed line (6.4 PFU). ND = not detectable. 

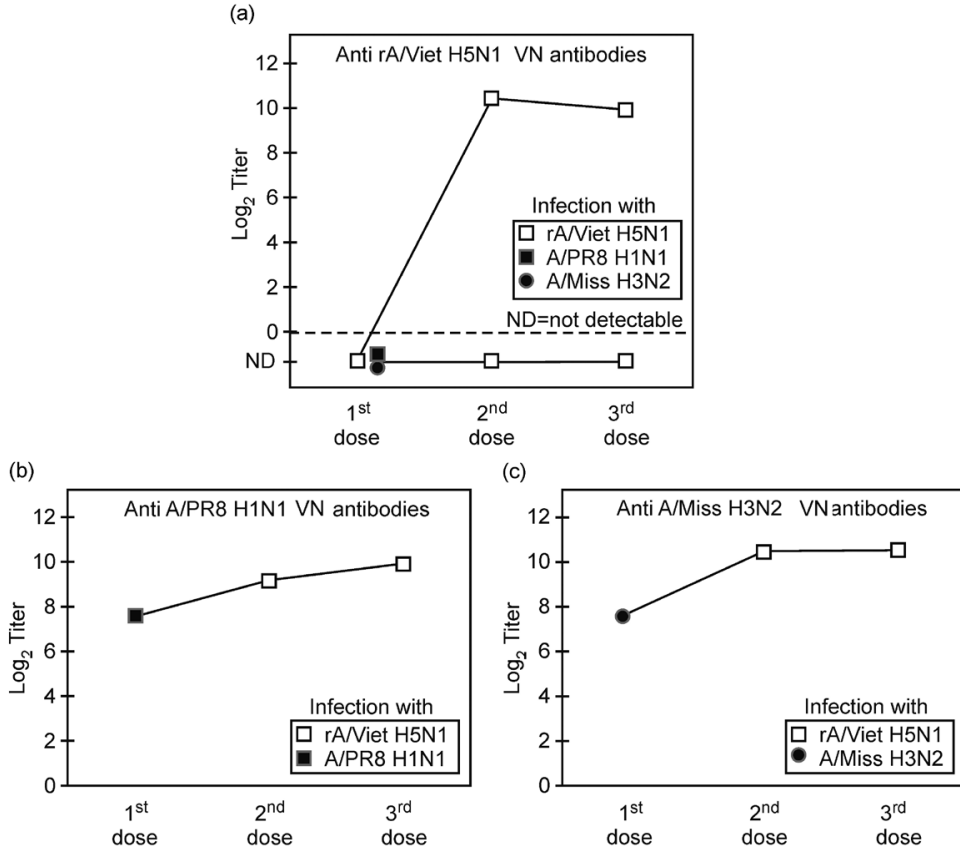

Fig. 3

Titers of virus-neutralizing antibodies specific to virus rA/Vietnam (H5 subtype, avian) (a), A/PR8 (H1 subtype, human) (b) or A/Miss (H3 subtype, human) (c) in sera of BALB/c mice after repeated infection with $\mathrm{rA} /$ Vietnam virus, or after infection with one sublethal dose of human IAV (H1 or H3) and subsequently with two doses of avian (H5) virus

Analysis of virus-neutralizing antibody response of mice infected with human IAV and subsequently with avian rA/Vietnam (H5N1) virus

The above scheme of infection was also used for the analysis of antibody response to the $\mathrm{H} 5$ virus induced after repeated infection of naive mice with rA/Vietnam (H5N1), or after infection of mice previously exposed to sub-lethal dose of human virus of $\mathrm{H} 1$ or $\mathrm{H} 3$ subtype and then infected with $\mathrm{H} 5$ avian virus. No $\mathrm{H} 5$-specific VN antibodies were detected in the sera of mice infected with one dose of $\mathrm{H} 5$ virus, but after the second infective dose of this virus, a detectable level of VN antibodies was elicited (Fig. 3). Surprisingly, no H5-specific $\mathrm{VN}$ antibodies were detected in the sera of mice infected with $\mathrm{H} 5$ virus after their previous infection with human IAV (H1 or $\mathrm{H} 3$ subtype). In contrast, the $\mathrm{VN}$ antibodies specific to $\mathrm{H} 1$ or $\mathrm{H} 3$ viruses used for primary infection were elicited in mice already after a single dose of the human virus and their titers increased after the subsequent infection of mice with $\mathrm{H} 5$ virus, similarly as it was shown for the $\mathrm{H} 4$ virus (see above).

\section{Discussion}

In this study we aimed to analyze the level of biologically active avian IAV-specific antibodies after previous exposure of animals to human IAV. Following intranasal infection with an avian non-adapted IAV A/Duck, no infectious virus was detected in mouse lungs. Analysis of biologically active antibodies, however, revealed that antibodies reducing virus replication of $\mathrm{H} 4$ virus were produced. The infection of mice with a sublethal dose of human IAV ( $\mathrm{H} 3$ or $\mathrm{H} 1)$ followed by infection with non-replicating avian $\mathrm{H} 4$ virus resulted in a significant antibody response specific to $\mathrm{H} 4$ as well as to $\mathrm{H} 3$ or $\mathrm{H} 1$ viruses. Strangely, when the infection with human IAV was followed by the infection with avian IAV of $\mathrm{H} 5$ subtype, no VN antibodies specific to this avian IAV were detected. This means that individuals could be protected against the human viruses, but their immune system was not able to react by producing $\mathrm{VN}$ antibodies specific to the corresponding new avian virus of $\mathrm{H} 5$ subtype. This could be related to the ability of $\mathrm{H} 5$ viruses to induce a strong cytokine response after infection (Cheung et al., 2002; Wong and Yeng, 2006; Xie et al., 2014) or it could be the impact of the original antigenic sin (OAS). Kim et al. (2009) showed that sequential infection of mice with live viruses caused much more profound original antigenic sin than their infection following immunization with whole inactivated IAV vaccine.

OAS is a phenomenon in which prior exposure to an antigen results in a suboptimal immune response to a related new antigen and a very strong immune response to the prior 
antigen. We observed this phenomenon in our study also. We showed that the titer of antibodies neutralizing human IAV induced in sera of mice infected with a sublethal dose of human viruses of $\mathrm{H} 3$ or $\mathrm{H} 1$ subtype increased significantly after subsequent exposure of mice to avian viruses of $\mathrm{H} 4$ or $\mathrm{H} 5$ subtypes. The production of $\mathrm{H} 4$-specific VN antibodies after such double infection was not markedly influenced by the previous exposure of mice to human virus. No H5-specific VN antibodies, however, were elicited after previous infection of mice with human IAV. On the other hand, a population of antibodies reducing the replication of $\mathrm{H} 5$ virus, but not clearing it, was induced after the repeated infection with this mouse-adapted avian IAV (results not shown). These results correspond to the observation of Gray et al. (2014), who showed that many infections of humans with avian IAV (of subtypes H4, H5, H6, H9 or H12) were subclinical with generally none or only very low titers of $\mathrm{VN}$ antibodies having been detected. This phenomenon might influence the process of adaptation of avian viruses to mammalian hosts, including humans.

In our work we showed that a population of cross-reactive antibodies is induced after a sequential infection of mice with human and avian IAV. These antibodies also include HA2-specific antibodies. HA2 gp is a relatively conserved protein, and some HA2 epitopes are even shared among HA subtypes (Kostolanský et al., 2002; Varečková et al., 2008). HA2- specific antibodies recognizing HA stem were shown to be protective (Gocník et al., 2007, 2008; Prabhu et al., 2009; Sui et al., 2009; Wang et al., 2010; Staneková et al., 2011; Janulíková et al., 2012), though they do not mediate virus neutralization by blocking the receptor-binding site on HA. We therefore suggest that anti-stem HA antibodies could help individuals exposed to dangerous avian IAV to overcome the infection in a subclinical manner.

Based on our results, we can conclude that the contact of humans with avian IAV without proved clinical symptoms of disease might be sufficient for the induction of biologically active antibody response. Consequently, these antibodies could represent the immune pressure on the partially adapted viruses of avian origin and fuel the process of their adaptation to mammals or elimination of viruses with limited replication from the human population before their adaptation to the new host.

Acknowledgements. The authors of this work wish to thank Mrs. M. Némethová and Mrs. M. Mišovičová for their excellent technical assistance. This work was supported by the grants VEGA 2/0176/12, VEGA 2/0146/15, VEGA 2/0100/13, VEGA-2/0153/14, VEGA 2/0152/14 from the Scientific Grant Agency of Ministry of Education of Slovak Republic and Slovak Academy of Sciences and by grants APVV-0250-10 and DO7RP-0025-2010 from the Slovak Research and Development Agency.

\section{References}

Blazejewska P, Koscinski L, Viegas N, Anhlan D, Ludwig S, Schughart K (2011): Pathogenicity of different PR8 influenza A virus variants in mice is determined by both viral and host factors. Virology 412, 36-45. http://dx.doi. org/10.1016/j.virol.2010.12.047

Boivin S, Hart DJ (2011): Interaction of the Influenza A Virus Polymerase PB2 C-terminal Region with Importin a Isoforms Provides Insights into Host Adaptation and Polymerase Assembly. J. Biol. Chem. 286, 10439-10448. http://dx.doi.org/10.1074/jbc.M110.182964

Bommakanti G, Citron MP, Hepler RW, Callahan C, Heidecker GJ, Najar TA, Lu X, Joyce JG, Shiver JW, Casimiro DR, ter Meulen J, Liang X, Varadarajan R (2010): Design of an HA2-based Escherichia coli expressed influenza immunogen that protects mice from pathogenic challenge. Proc. Natl. Acad. Sci. USA 107, 13701-13706. http:// dx.doi.org/10.1073/pnas.1007465107

Chandrasekaran A, Srinivasan A, Raman R, Viswanathan K, Raguram S, Tumpey TM, Sasisekharan V, Sasisekharan $\mathrm{R}$ (2008): Glycan topology determines human adaptation of avian $\mathrm{H} 5 \mathrm{~N} 1$ virus hemagglutinin. Nat. Biotechnol. 26,107-101. http://dx.doi.org/10.1038/nbt1375

Chang SY, Pi-Han Lin (2013): Serological survey in close contacts with a confirmed case of H7N9 influenza in Taiwan. http://dx.doi.org/10.1016/j.jinf.2013.08.001. http://dx.doi. org/10.1016/j.jinf.2013.08.001

Chen H, Yuan H, Gao R, Zhang J, Wang D, Xiong Y, Fan G, Yang F, Li X, Zhou J, Zou S, Yang Cheung CY, Poon LL, Lau AS, Luk W, Lau YL, Shortridge KF, Gordon S, Guan Y, Peiris JS (2002): Induction of proinflammatory cytokines in human macrophages by influenza A (H5N1) viruses: a mechanism for the unusual severity of human disease? Lancet 360, 1831-1837. http://dx.doi.org/10.1016/S01406736(02)11772-7

L, Chen T, Dong L, Bo H, Zhao X, Zhang Y, Lan Y, Bai T, Dong J, Li Q, Wang S, Zhang Y, Li H, Gong T, Shi Y, Ni X, Li J, Zhou J, Fan J, Wu J, Zhou X, Hu M, Wan J, Yang W, Li D, Wu G, Feng Z, Gao GF, Wang Y, Jin Q, Liu M, Shu $Y$ (2014): Clinical and epidemiological characteristics of a fatal case of avian influenza A H10N8 virus infection: a descriptive study. Lancet 383, 714-721. http://dx.doi. org/10.1016/S0140-6736(14)60111-2

De Jong JC, Class EJC, Osterhaus ADME, Webster RG, Lim WL (1997): A pandemic warning? Nature 389, 554. http:// dx.doi.org/10.1038/39218

Du L, Guangyu Zhao, Shihui Sun, Xiujuan Zhang, Xiaojun Zhou, Yan Guo, Ye Li, Yusen Zhou, Shibo Jiang (2013): A Critical HA1 Neutralizing Domain of H5N1 Influenza in an Optimal Conformation Induces Strong Cross-Protection PLOS One 8, e53568. http://dx.doi.org/10.1371/journal. pone. 0053568

Fislová T, Gocník M, Sládková T, Ďurmanová V, Rajčáni J, Varečková E, Mucha V, Kostolanský F (2009): Multiorgan distribution of human influenza A virus strains observed 
in mouse model. Arch. Virol. 154, 409-419. http://dx.doi. org/10.1007/s00705-009-0318-8

Freidl GS, Meijer A, E de Bruin, M de Nardi, O Munoz, I Capua, A C Breed, Harris K, Hill A, Kosmider R, Banks J, S von Dobschuetz, K Stark, B Wieland, K Stevens, S van der Werf, V Enouf, K van der Meulen, K Van Reeth, G Dauphin, M Koopmans, FLURISK Consortium, www.eurosurveillance.org, (2014): Influenza at the animal-human interface: a review of the literature for virological evidence of human infection with swine or avian influenza viruses other than $\mathrm{A}(\mathrm{H} 5 \mathrm{~N} 1)$.

Gabriel G, Klingel K, Otte A, Thiele S, Hudjetz B, Arman-Kalcek G, Sauter M, Shmidt T, Rother F, Baumgarte S, Keiner B, Hartmann E, Bader M, Brownlee GG, Fodor E, Klenk HD (2011): Differential use of importin- $\alpha$ isoforms governs cell tropism and host adaptation of influenza virus. Nat. Commun. 2, 156. http://dx.doi.org/10.1038/ ncomms 1158

Gabriel G, Czudai-Matwich V, Klenk HD (2013): Adaptive mutations in the H5N1 polymerase complex. Virus Res. 178, 53-62. http://dx.doi.org/10.1016/j.virusres.2013.05.010

Garten RJ, Davis CT, Russell CA, Shu B, Lindstrom S, Balish A, Sessions WM, Xu X, Skepner E, Deyde V, Okomo-Adhiambo M, Gubareva L, Barnes J, Smith CB, Emery SL, Hillman MJ, Rivailler P, Smagala J, de Graaf M, Burke DF, Fouchier RA, Pappas C, Alpuche-Aranda CM, López-Gatell H, Olivera H, López I, Myers CA, Faix D, Blair PJ, Yu C, Keene KM, Dotson PD Jr., Boxrud D, Sambol AR, Abid $\mathrm{SH}$, St George K, Bannerman T, Moore AL, Stringer DJ, Blevins P, Demmler-Harrison GJ, Ginsberg M, Kriner P, Waterman S, Smole S, Guevara HF, Belongia EA, Clark PA, Beatrice ST, Donis R, Katz J, Finelli L, Bridges CB, Shaw M, Jernigan DB, Uyeki TM, Smith DJ, Klimov AI, Cox NJ (2009): Antigenic and genetic characteristics of swine-origin $2009 \mathrm{~A}(\mathrm{H} 1 \mathrm{~N} 1)$ influenza viruses circulating in humans. Science 325, 197-201. http://dx.doi. org/10.1126/science.1176225

Gocník M, Fislová T, Sládková T, Mucha V, Kostolanský F, Varečková E (2007): Antibodies specific to the HA2 glycopolypeptide of influenza A virus haemagglutinin with fusion-inhibition activity contribute to the protection of mice against lethal infection. J. Gen. Virol. 88, 951-955. http://dx.doi.org/10.1099/vir.0.82563-0

Gocník M, Fislová T, Mucha V, Sládková T, Russ G, Kostolanský F, Varečková E (2008): Antibodies induced by the HA2 glycopolypeptide of influenza virus haemagglutinin improve recovery from influenza A virus infection. J. Gen. Virol. 89, 958-967 http://dx.doi.org/10.1099/vir.0.83524-0

Gray GC, Krueger WS, Chum C, Putnam DS, Wierzba TF, Heil GL, Anderson BD, Yasuda CY, Williams M, Kasper MR, Saphonn V, Blair PJ (2014): Little Evidence of Subclinical Avian Influenza Virus Infections among Rural Villagers in Cambodia. PLOS One 9, e97097. http://dx.doi. org/10.1371/journal.pone.0097097

Hatta M, Kawaoka Y (2002): The continued pandemic threat posed by avian influenza viruses in Hong Kong. Trends Microbiol. 10, 340-344. http://dx.doi.org/10.1016/S0966$\underline{842 X(02) 02388-0}$
Horby P, Nguyen NY, Dunstan SJ, Baillie JK (2012): The Role of Host Genetics in Susceptibility to Influenza: A Systematic Review. PLoS ONE 7, e33180. http://dx.doi.org/10.1371/ journal.pone.0033180

Hui DS, Hayden FG (2014): Host and viral factors in emergent influenza virus infections, CID 58, EDITORIAL COMMENTARY.

Imai M, Kawaoka Y (2012): The role of receptor binding specificity in interspecies transmission of influenza viruses. Curr. Opin. Virol. 2, 160-167. http://dx.doi.org/10.1016/j. coviro.2012.03.003

Janulíková J, Staneková Z, Mucha V, Kostolanský F and Varečková E (2012): Two distinct regions of HA2 glycopolypeptide of influenza virus hemaglutinin elicit cross-protective immunity against influenza. Acta Virol. 56, 169-176. http://dx.doi.org/10.4149/av $201203 \quad 169$

Kaplan BS, Webby RJ (2013): The avian and mammalian host range of highly pathogenic avian H5N1 influenza. Virus Res. 178, 3-11. http://dx.doi.org/10.1016/j.virusres.2013.09.004

Kim JH, Skountzou I, Compans R, Jacob J (2009): Original Antigenic Sin Responses to Influenza Viruses. J. Immunol. 183, 3294-3301. http://dx.doi.org/10.4049/jimmunol.0900398

Kostolanský F, Varečková E, Betáková T, Mucha V, Russ G, Wharton S (2000): The strong positive correlation between effective affinity and infectivity neutralization of highly crossreactive monoclonal antibody IIB4, which recognizes antigenic site B on influenza A virus haemagglutinin. J. Gen. Virol. 81, 1727-1735.

Kostolanský F, Mucha V, Slováková R, Varečková E. (2002): Natural influenza A virus infection of mice elicits strong antibody response to HA2 glycopolypeptide. Acta Virol. 46, 229-236.

Liu A, Sun J, Cai J, Miao Z, Lu M, Qin S, Wang X, Lv H, Yu Z, Amer S, Chai Ch (2013): Epidemiological, clinical and viral characteristics of fatal cases of human avian influenza A (H7N9) virus in Zhejiang Province, China. J. Infect. 67, 595e605. http://dx.doi.org/10.1016/j.jinf.2013.08.007

Prabhu N, Prabakaran M, Ho Hui-Ting, Velumani S, Qiang J, Goutama M, Kwang J (2009): Monoclonal antibodies against the fusion peptide of hemagglutinin protect mice from lethal influenza A virus H5N1 infection. J. Virol. 83, 2553-2562. http://dx.doi.org/10.1128/JVI.02165-08

Reed LJ, Muench H (1938): A simple method for estimating fifty percent end points. Am. J. Hyg. 27, 493-497.

Russ G, Styk B, Poláková K, Varečková E (1976): Competitiveinhibition radioimmunoassay for influenza virus envelope antigens. Acta Virol. 20, 460-465.

Sandrock C, Kelly T (2007): Clinical review: Update of avian influenza A infections in humans. Critical Care 11, 209. http:// dx.doi.org/10.1186/cc5675

Schmolke M, Manicassamy B, Pena L, Sutton T, Hai R, Varga ZT, Hale BG, Steel J, Pérez DR, García-Sastre A (2011): Differential Contribution of PB1-F2 to the Virulence of Highly Pathogenic H5N1 Influenza A Virus in Mammalian and Avian Species. PLoS Pathog. 7, e1002186. http://dx.doi. org/10.1371/journal.ppat.1002186

Seo SH, Hoffmann E, Webster RG (2002): Lethal H5N1 influenza viruses escape host anti-viral cytokine responses. Nat. Med. 8, 950-954. http://dx.doi.org/10.1038/nm757 
Seo SH, Hoffmann E, Webster RG (2004): The NS1 gene of H5N1 influenza viruses circumvents the host anti-viral cytokine responses. Virus. Res. 103, 107-113. http://dx.doi. org/10.1016/j.virusres.2004.02.022

Staneková Z, Király J, Stropkovská A, Mikušková T, Mucha, Kostolanský F, Varečková, E (2011): Heterosubtypic protective immunity against influenza A virus induced by fusion peptide of the hemagglutinin in comparison to ectodomain of M2 protein. Acta Virol. 55, 61-67. http://dx.doi. org/10.4149/av $201101 \quad 61$

Staneková Z, Adkins I, Kosová M, Janulíková J, Šebo P and Varečková E (2013): Heterosubtypic protection against influenza induced by adenylate cyclase toxids delivering conserved HA2 subunit of hemagglutinin. Antiviral Res. 97, 24-35. http://dx.doi.org/10.1016/j.antiviral.2012.09.008

Stropkovska A, Mucha V, Fislova T, Gocnik M, Kostolansky F, Vareckova E (2009): Broadly cross-reactive monoclonal antibodies against HA2 glycopolypeptide of influenza A hemaglutinin of $\mathrm{H} 3$ subtype reduce replication of influenza A viruses of human and avian origin. Acta Virol. 53, 15-20. http://dx.doi.org/10.4149/av 2009 $01 \quad 15$

Subbarao K, Klimov A, Katz J, Regnery H, Lim W, Hall H, Perdue M, Swayne D, Bender C, Huang J, Hemphill M, Row T, Shaw M, Xu X, Fukuda K, Cox NJ (1998): Characterization of an avian influenza $\mathrm{A}(\mathrm{H} 5 \mathrm{~N} 1)$ virus isolated from a child with a fatal respiratory illness. Science 279, 393-396. http://dx.doi.org/10.1126/science.279.5349.393

Subbarao K, Katz J (2000): Avian influenza viruses infecting humans. Cell. Mol. Life Sci. 57, 1770-1784. http://dx.doi. org/10.1007/PL00000657

Subbarao K, Swayne DE, Olsen CW (2006): Epidemiology and control of human and animal influenza. In Influenza Virology. Current Topics. Caister Academic Press, UK, pp. 229-280.

Sui J, Hwang WC, Perez S, Wei G, Aird D, Chen LM, Santelli E, Stec B, Cadwell G, Ali M, Wan H, Murakami A, Yammanuru A, Han T, Cox NJ, Bankston LA, Donis RO, Liddington RC, Marasco WA (2009): Structural and functional bases for broad-spectrum neutralization of avian and human influenza A viruses. Nat. Struct. Mol. Biol. 16, 265-273. http://dx.doi.org/10.1038/nsmb.1566

Tkáčová M, Varečková E (1996): A sensitive one-step immunocapture EIA for rapid diagnosis of influenza A. J. Virol. Methods 60, 65-71. http://dx.doi.org/10.1016/0166-0934(96)02046-0

Varečková E, Betáková T, Mucha V, Soláriková L, Kostolanský F, Waris M, Russ G (1995): Preparation of monoclonal antibodies for the diagnosis of influenza $\mathrm{A}$ infection using different immunization protocols. J. Immunol. Methods 180, 107-116. http://dx.doi.org/10.1016/00221759(94)00307-I
Varečková E, Cox N, Klimov A (2002): Evaluation of the subtype specificity of monoclonal antibodies raised against H1and $\mathrm{H} 3$ subtypes of human influenza A virus hemagglutinins. J. Clin. Microbiol. 40, 2220-2223. http://dx.doi. org/10.1128/JCM.40.6.2220-2223.2002

Varečková E, Wharton S, Mucha V, Gocník M, Kostolanský F (2003): A monoclonal antibody specific to the HA2 glycoprotein of influenza A virus hemagglutinin that inhibits its fusion activity reduces replication of the virus. Acta Virol. 49, 229-236.

Varečková E, Mucha V, Kostolanský F, Gubareva LV, Klimov A (2008): HA2-specific monoclonal antibodies as tools for differential recognition of influenza A virus antigenic subtypes. Virus Res. 132, 181-186. http://dx.doi. org/10.1016/j.virusres.2007.10.004

Varečková E, Mucha V, Kostolansky F (2013): HA2 glycopolypeptide of influenza A virus and immunity. Acta Virol. 57, 247-256. http://dx.doi.org/10.4149/av $2013 \quad 02 \quad 247$

Wang TT, Tan GS, Hai R, Pica N, Petersen E, Moran TM, Palese $\mathrm{P}$ (2010): Broadly protective monoclonal antibodies against $\mathrm{H} 3$ influenza viruses following sequential immunization with different hemagglutinins. PLoS Pathog. 6, e1000796. http://dx.doi.org/10.1371/journal.ppat.1000796

Wang $\mathrm{CH}$, Hongjie Yu, Horby PW, Bin Cao, Peng Wu, Shigui Yang, Hainv Gao, Hui Li, Tim K. Tsang, Qiaohong Liao, Zhancheng Gao, Dennis K M Ip, Hongyu Jia, Hui Jiang, Bo Liu, Michael Y. Ni, Xiahong Dai, Fengfeng Liu, Nguyen Van Kinh, Nguyen Thanh Liem, Tran Tinh Hien, Yu Li, Juan Yang, Joseph T. Wu, Yaming Zheng, Gabriel M. Leung, Jeremy J. Farrar,Benjamin J. Cowling, Timothy M. Uyeki, Lanjuan Li (2014): Comparison of Patients Hospitalized With Influenza A Subtypes H7N9, H5N1, and 2009 Pandemic H1N1. CID 58, 1095. http://dx.doi. org/10.1093/cid/ciu053

Webster RG (2006): H5 influenza viruses. In Kawaoka Y (Ed.): Influenza Virology. Current Topics. Caister Academic Press, UK, pp. 281-298.

Wong SSY, Yuen K-Y (2006): Avian influenza infections in humans. Chest 129, 156-168. http://dx.doi.org/10.1378/ chest.129.1.156

World Health Organization. Monthly Risk Assessment Summary Influenza at the Human-Animal Interface. Available at http://www.who.int/influenza/human-animal_interface/ Influenza.

Xie J, Zhang S, Hu Y, Li D, Cui J, Xue J, Zhang G, Khachigian LM, Wong J, Sun L, Wang M (2014): Regulatory roles of c-jun in $\mathrm{H} 5 \mathrm{~N} 1$ influenza virus replication and host inflammation. Bioch. Biophys. Acta 1842, 2479-2488. http://dx.doi. org/10.1016/j.bbadis.2014.04.017 